Ann. Nutr. Metab. 1984;28:I-VI

\title{
Contents, Vol. 28, 1984
}

European Journal of Nutrition, Metabolic Diseases and Dietetics

Journal europeen de nutrition, des maladies metaboliques et de dićtétique

Europãische Zeitschrift fttr Ernährungswissenschaft, Stoffwechselstorungen

und Diätetik

Annals of Nutrition and Metabolism (formerly Annales de la Nutrition et de $\Gamma$ Alimentation' and 'Nutrition and Metabolism') is recognised by the 'Federation of European Nutrition Societies' (FENS) as its official journal Founded 1959 as 'Nutritio et Dieta' and J. Trémolières by E. Azerad, H. Kapp Former Main Editor: A. Wretlind (1961-1969)

Main Editor Editorial Board

N. Zöllner, München L.G. Alcindor, Paris I. Macdonald, London Associate Editors

E.M. Widdowson, Cambridge G. Debry, Nancy B. Brubacher, Basel H.K. Mangold, Miinster

J.W.T. Dickerson, Guildford F. Falkner, Berkeley, Calif. C.F. Mills, Aberdeen D.J. Naismith, London

Ch. Frayssinet, Villejuif K.R. Norum, Oslo

Executive Editor L. Gueguen, Jouy-en-Josas G. Schlierf, Heidelberg

G. Wolfram, Freising L. Hambraeus, Uppsala D.H. Shmerling, Zurich

K. Hellström, Stockholm M.A. Spadoni, Roma

S. Heyden, Durham, N.C. A.J. Vergroesen,

F.A. Hommes, Augusta, Ga. Vlaardingen-Duiven

B. Jacotot, Créteil A. Wretlind, Stockholm

D.E.M. Lawson, Cambridge Advisory Board, FENS H. Zucker, München

Austria Netherlands

B.M. Brandstetter, Wien I.R.J.J. Hermus, Boven-Leeuwen

Bulgaria Norway

L. Balabanski, Sofia K.R. Norum, Oslo

Denmark Poland

E. Aaes-Jørgensen, København S. Berger, Warzawa

East Germany Spain

H. Schmandke, G. Varela, Madrid

Bergholz-Rehbrücke Sweden

Finland L. Hambraeus, Uppsala

H. Koskinen, Helsinki Switzerland

Great Britain E. Jéquier, Lausanne

J. Dickerson, Guildford West Germany 
Greece

A. Trichopoulou, Athens Italy

E. Lanzola, Pavia G. Schlierf, Heidelberg

S. Karger $\square$ Medical and Scientific Publishers $\square$ Basel $\cdot$ München $\square$ Paris $\square$ London $\square$ New York

- Tokyo $\cdot$ Sydney

Drug Dosage

The authors and the publisher have exerted every effort to ensure that drug selection and dosage set forth in this text are in accord with current recommendations and practice at the time of publication. However, in view of ongoing research, changes in government regulations, and the constant flow of information relating to drug therapy and drug reactions, the reader is urged to check the package insert for each drug for any change in indications and dosage and for added warnings and precautions. This is particularly important when the recommended agent is a new and/or infrequently employed drug.

All rights reserved.

No part of this publication may be translated into other languages, reproduced or utilized in any form or by any means, electronic or mechanical, including photocopying, recording, microcopying, or by any information storage and retrieval system, without permission in writing from the publisher or, in the case of photocopying, direct payment of a specified fee to the Copyright Clearance Center (see 'Information for Readers and Subscribers').

(C) Copyright 1984 by S. Karger AG, P.O. Box, CH-4009 Basel (Switzerland)

Printed in Switzerland by Thür AG Offsetdruck, Pratteln

Contents Vol. 28,1984

No. 1 Effects of Guar-Enriched Pasta in the Treatment of Diabetes and Hyperlipidemia

Gatti, E.; Catenazzo, G.; Camisasca, E.; Torn, A.; Denegri, E.; Sirtori, C.R 1

Valeur calorique de $\Gamma$ alimentation et couverture des apports nutritionnels conseillés en vitamines de Thomme adult. Principaux vecteurs alimentaires de vitamines

Mareschi, J.P.; Cousin, F.; Villeon, B. de la; Brubacher, G.B 11

Effect of Dietary Eggs on Liver and Plasma Proteins of Rats. I. Synthesis of Serum Low-

Density Lipoproteins

Nadkarni, G.D 24

Nitrogen Balance Studies in Patients with Uremia during Treatment with Protein-Reduced Diet and Supplementation with Essential Amino Acids or Keto Acids

Attman, P.-O.; Bucht, H.; Isaksson, B.; Uddebom, G 29

Effects of Fenugreek Seeds on Endocrine Pancreatic Secretions in Dogs

Ribes, G.; Sauvaire, Y.; Baccou, J.-C; Valette, G.; Chenon, D.; Trimble, E.R.; Loubatières-Mariani, M.-M 37

Response of the Reproductive System of Male Rats to Protein and Zinc Deficiency during Puberty

Salem, S.I.; Coward, W.A.; Lunn, P.G.; Hudson, G.J 44

Glycosyltransferase Activities in the Rat Intestinal Mucosa: Comparison between Standard

Commercial and Semi-Synthetic Diets

Biol, M.-C; Martin, A.; Paulin, C; Hemming, F.; Louisot, P.; Richard, M 52

No. 2 Intracellular Electrolytes and Hormonal Parameters during Weight Reduction

Zidek, W.; Karoff, C; Losse, H.; Vetter, H 65

Changes in Serum Albumin, Transferrin and Amino Acid Indices during the First Month of 
Life in Small-for-Date Infants

Faus, M.J.; Gil, A.; Robles, R.; Sánchez-Pozo, A.; Pita, M.L.; Sanchez-Medina, F. . 70 Apports alimentaires en fer dans une population de femmes françaises en age de procréer

Hercberg, S.; Soustre, Y.; Galán, P.; Berthier, A.M.; Suquet, J.P.; Dupin, H

Biochemical Observations on Rat Aortas: Effect of Protein Refeeding after a Protein Depletion

Period

Bydlowski, S.P.; Stivaletti, V.L.G.; Douglas, C.R 85

Effects of a Large Dose of Retinol or Retinoic Acid on the Thyroid Hormones in the Rat

Garcin, H; Higueret, P.; Amoikon, K 92

Brown Adipose Tissue Metabolism in Lactating Rats: The Effect of Litter Size

Isler, D.; Trayhurn, P.; Lunn, P.G 101

Incorporation and Secretion of $45 \mathrm{Ca}$ after per os Application of $45 \mathrm{Ca}$ Salts of Phosphatidic

Acids

Rauch, P.; Kás, J 110

IV Contents

Teneur en cholesterol des lipoprotéines légères chez le lapin hypercholestérolémique intoxiqué ou non par Гoxyde de carbone

Alcindor, L.G.; Belegaud, J.; Aalam, H.; Piot, M.C.; Héraud, C; Boudène, C

117

Exercise and Protein Catabolism in Women

Plante, R.I.; Houston, M.E 123

Metabolic Fate of Ammonium Salts of Synthetic Phosphatidic Acids after Application per os Rauch, P.; Kás, J 130

No. 3 Influence of Dietary Casein or Soy Protein on Serum Lipids and Lipoproteins of Monkeys (Macaca fascicularis)

Barth, C.A.; Pfeuffer, M.; Hahn, G 137

Vitamin D Intake, Sunlight Exposure and 25-Hydroxyvitamin D Levels in the Elderly

during One Year

Lamberg-Allardt, C 144

Endogenous Urea as a Nitrogen Source for Microorganisms of the Rabbit Digestive Tract

Viallard, V 151

Digestibility and Dietary Quality of Nonacetylated and Acetylated Vicia faba Proteins in

Maintenance. Studies on 15N-Labelled Adult Rats

Bergner, H.; Seidler, W.; Simon, O.; Schmandke, H 156

Postheparin Lipolytic Activities in Zucker Rats Fed with Sucrose- or Cornstarch-Rich

Diets

Basílico, M.Z.; Lombardo, Y.B.; Chanussot, F.; Debry, G 164

Influence of Diets Containing Different Levels of Vicia faba L. as Source of Protein on Body

Protein Composition and Nitrogen Balance of Growing Rats

Martinez, J.A.; Larralde, J 174

Low 25-Hydroxyvitamin D and Normal Serum Calcium Concentrations in Saudi Arabia:

Riyadh Region

Sedrani, S.H 181

The Effect of $\alpha$-Tocopherol and Ascorbic Acid on the Serum Lipid Peroxide Level in Elderly People

Wartanowicz, M.; Panczenko-Kresowska, B.; Ziemlański, S.; Kowalska, M.; Okolska, G. 186

Dietary Protein-Dependent Modification of Serum Cholesterol Level in Rats. Significance of 
the Arginine/Lysine Ratio

Sugano, M.; Ishiwaki, N.; Nakashima, K 192

Announcements 200

No. 4 The Effect of Dietary Linoleic Acid and Pectin on Lipoprotein and Apolipoprotein Al

Concentrations in Rhesus Monkeys

Heine, R.J.; Schouten, J.A.; Gent, CM. van; Havekes, L.M.; Koopman, P.A.R.; Veen,

E.A. van der 201

Time Course of Serum Glucoregulatory Variables and Lipids following Neonatal Thymec-

tomy of Diabetes-Prone and Control BB Wistar Rats Fed a Defined Diet

Scott, F.W.; Trick, K.D.; Hynie, I.; Braaten, J.T.; Nera, E.A207

Transketolase Activities and Body Weight Changes in Rats on Low Protein Diets

Ette, S.I 220

Contents

$\mathrm{V}$

Differences in Dietary-Induced Thermogenesis following the Ingestion of Various

Carbohydrates

Macdonald, 1226

Effects of the Diet on the Composition of Human Milk

Harzer, G.; Dieterich, I.; Haug, M 231

Vitamin B6 Status and Static Muscle Function. 2 Case Reports

Wirth, J.C.; Lohman, T.G 240

Diet-Induced Thermogenesis in Man: Thermic Effects of Single Proteins' Carbohydrates and

Fats Depending on Their Energy Amount

Karst, H.; Steiniger, J.; Noack, R.; Steglich, H.-D 245

Effect of Carbohydrate Diet Type upon Obesity and Hyperlipemia in the Zucker fa/fa Rat

Basilico, M.Z.; Chanussot, F.; Villaume, C; Lombardo, Y.B.; Debry, G 253

Announcement 260

No. 5 Wirkung von Nahrungslipiden auf mikrosomale Elektronentransportproteine der Ratte

Domke, I.; Weis, W 261

Metabolic Balance of the Ovine Fetus during the Fed and Fasted States

Lemons, J.A.; Schreiner, R.L 268

Albumin-Synthesizing Capacity of Hepatocytes Isolated from Rats Fed Diets Differing in

Protein and Energy Content

Smith, J.E.; Lunn, P.G 281

Studies on the in vivo Utilisation and the in vitro Enzymatic Reduction of Methionine

Sulphoxide in Rats and Rat Tissues

Aksnes, A 288

Relative Bioactivity of Alpha- and Gamma-Tocopherol Calculated from Respiration Parameters

in Rat Liver Mitochondria

Schäfer, H.; Elmadfa, 1

Secretion and Hepatic Removal of Insulin in Female Obese Subjects with Reactive Hypo-

glycemia

Bonora, E.; Coscelli, C; Butturini, U 305

Effects of Excess Dietary L-Cystine on the Rat Plasma Lipoproteins

Sérougne, C; Férézou, J.; Rukaj, A 311

No. 6 Vitamin A Transfer to the Fetus and to the Amniotic Fluid in Rhesus Monkey (Macaca 
mulatta)

Vahlquist, A.; Nilsson, S 321

Effects of Several Alimentary Fats on Serum Lipids during Long-Term Stabilized Diets

Lasserre, M.; Kerautret, M.; Navarro, N.; Martin, C; Jacotot, B 334

Postnatal Development of the Sterol and Nonsterol Mevalonate Metabolism in Chick Liver and Kidneys. Effect of Cholesterol Feeding

Aguilera, J.A.; Linares, A.; Marco, C; Arce, V.; Garcia-Peregrin, E342

Serum Branched-Chain Amino and Keto Acid Response to a Protein-Rich Meal in Man

Schauder, P.; Schroder, K.; Langenbeck, U 350

Pulmonary and Hepatic Fatty Acid Synthesis. HI. Control of Hexose Monophosphate Shunt

Pathway by $3,5,3^{\prime}$-L-Triiodothyronine

Das, D.K.; Neogi, A 357

VI

Contents

Distribution of Hepatic Ribosomes between Different Functional States in Well-Fed and

Protein-Energy-Deficient Rats

Enwonwu, CO.; Okolie, E.E 367

High Density Lipoprotein Cholesterol and Apoprotein Al in Healthy Volunteers during

Long-Term Moderate Alcohol Intake

Couzigou, P.; Fleury, B.; Crockett, R.; Rautou, J.J.; Blanchard, P.; Lemoine, F.;

Richard-Molard, B.; Amouretti, M.; Béraud, C

377

Vitamin Status during Puerperium and Lactation

Dostálová, L 385

Letter to the Editor

Carbohydrate Sensitivity, Triglycerides and Uric Acid

Halpern, MJ 409

Announcement $\quad 410$

Author Index 411

Subject Index 413 